\title{
ANTÓNIO MACHADO GUERREIRO
}

\author{
Raquel Soeiro DE Brito ${ }^{1}$
}

Conheci o Dr. António Machado Guerreiro no Centro de Estudos Geográficos (CEG) da Faculdade de Letras da Universidade de Lisboa, nos finais da década de 1940, era eu ainda estudante; isto, porque o professor Orlando Ribeiro preferia, às salas da velha, triste e húmida Faculdade da Rua da Academia das Ciências, dar as suas aulas no Centro, onde tinha todos os materiais necessários. Por isso, Machado Guerreiro era para nós, alunos, uma importante personalidade no nosso ambiente de trabalho, do qual Orlando Ribeiro e Mariano Feio eram os expoentes máximos.

Nos primeiros dias de convívio quase nos intimidava tanto quanto os Mestres, devido ao seu semblante simultaneamente severo e jocoso. Quem era aquele homem (nunca nos fora apresentado...) que tratava, com certa familiaridade, quase de igual para igual, embora com respeito, os nossos Professores? E que lugar ocupava no Centro, onde nós o víamos "fazer de tudo", desde consertar janelas desengonçadas a rever provas científicas dos Professores (e por vezes mesmo a dizer-lhes “... e se fosse assim, não seria melhor"?)

Esses dias de perplexidade passaram depressa; pouco tempo decorrido apercebemo-nos de que era um auxiliar precioso, uma "peça" de fundo naquela pequena comunidade científica, de quem íamos compreendendo a situação e o feitio, embora só mais tardiamente e, nem todos, nos fossemos conformando com o tom displicente com que nos parecia sermos tratados.

Chegou o ano de 1948 e com ele o afã da preparação do primeiro Congresso Internacional de Geografia após a II Guerra Mundial, que o Professor Orlando prometera aos dirigentes da União Geográfica Internacional (UGI) realizar em Lisboa - e que cumpriu, apesar das enormes dificuldades de todo o género.

Foi uma azáfama permanente: o pessoal do Centro foi aumentado com desenhadores a tempo parcial e ajudantes para a secretaria, já sob a direcção de Machado Guerreiro. Foi um ano de trabalho muito duro, mas de uma aprendizagem inigualável; e lá estava, sempre pronto, Machado Guerreiro a dar a sua colaboração nos mais diversos serviços. Recordo muito bem quanto a sua ajuda foi preciosa na compilação das comunicações e, mais ainda, na junção dos segmentos dos artigos que nos eram enviados, praticamente de todo o mundo; os do Brasil eram os mais complexos, porquanto, tanto quanto me lembro, raro foi o que chegou completo de uma só vez. E quando os 
mapas, ainda desenhados em papel vegetal, vinham cheios de montagens já descoladas e fora do sítio? Que trabalho de "puzzle" foi necessário fazer! Mas fomo-nos habituando ao seu modo um tanto ou quanto mordaz e trabalhando em enorme comunhão de boas vontades, como raramente vi igual.

Após a azáfama durante o Congresso, seguiu-se, poucos meses depois, a compilação do material definitivo para a publicação das Actas - 4 volumes, 1940 páginas, muitas dezenas de mapas e de fotografias. Foi trabalho que decorreu ao longo de dois anos, durante os quais Machado Guerreiro foi o meu principal ajudante, uma vez que o Professor Orlando Ribeiro me encarregara da execução desta tão árdua tarefa.

Depois, o Centro regressou à sua actividade normal: secretariado, preparação de material para as aulas e para os colóquios quinzenais, pois quer estes fossem da responsabilidade dos professores do Centro ou de convidados, era ao seu pessoal que cabia a parte material da respectiva organização.

Com a subida de Orlando Ribeiro a Vice-presidente da UGI e a sua presença em frequentes reuniões internacionais, tornou-se necessária toda uma preparação logística, de que, em parte, Machado Guerreiro também foi encarregado.

No meio de todas estas tarefas de carácter mais ou menos científico e de outras de ordem prática, uma vez que o Centro estando alojado numa casa velha, carecia, de vez em quando, de uma ou outra reparação... de que Machado Guerreiro se ocupava, quase não nos dávamos conta de que ele ia alimentando o seu espírito curioso, não só com múltiplas leituras (algumas delas indicadas pelos professores, Orlando, Mariano, Jorge Dias, e até por alguns de nós, os mais novos), como pela frequência dos cursos nocturnos do liceu, conseguindo em poucos anos o curso completo na Secção de Letras, que terminou em 1962 e, a seguir, pela inscrição na Faculdade de Letras da Universidade de Lisboa, no curso de Filologia Românica, que completaria no ano lectivo de 1967/68, com a apresentação de uma dissertação de índole etno-linguística. Durante todos estes anos continuou a trabalhar no CEG, com o mesmo estatuto e entusiasmo.

Entretanto, a pouco e pouco, fui deixando de frequentar assiduamente o CEG, por falta de tempo, ao longo dos anos lectivos, e por passar as chamadas "férias grandes" em trabalhos de investigação, principalmente em Missões de Estudo, da então Junta de Investigações do Ultramar. Este afastamento não me impediu de continuar a interessar-me pelo desenvolvimento da vida do Centro nem pela vida profissional de Machado Guerreiro; mesmo de longe e de tempos a tempos, fui sabendo da sua actividade de colaborador em algumas revistas científicas (no seu curriculum contam-se vários títulos), para além, claro, de todo o trabalho administrativo do CEG, que, pelos fins dos anos 70, dispunha de perto de meia centena de pessoas.

Machado Guerreiro conviveu com várias gerações de geógrafos do "viveiro" que era o CEG; a ele, afinal, todos os "velhos" do Centro muito devem - pela paciência com que tentava resolver alguns dos seus problemas, desde os de índole material até à revisão dos trabalhos a publicar, no que se manifestou, desde cedo, ser uma excelente ajuda.

Machado Guerreiro, como Orlando Ribeiro dizia muitas vezes, foi " metade do CEG", pelo menos desde fins dos anos 40 até meados da década de 70; e dezenas de anos decorridos, os mais antigos colaboradores do Centro ainda o recordam com saudade. 